\title{
The Contribution of Social Media Languages in Language Change and Character Building of The Students of IAIN Takengon
}

\author{
Sungkawati Kardi Wahyuningsih ${ }^{1 *}$, Andika Hariyanto Surbakti, Rahmanita Zakaria, Leni \\ Agustina Daulay, and Awal Kurnia Putra Nasution \\ \{kardisungkawati@gmail.com\} \\ ${ }^{12345}$ Department of Tarbiyah, [Institute Agama Islam Negeri Takengon]
}

\begin{abstract}
The aim of this study was finding out the language change and character education in reference to the contribution of social media languages of the students IAIN Takengon. This research was categorized into a case study by using descriptive qualitative approach. The participants were 300 students of IAIN Takengon. The research instrument was in the form of questionnaire, observation sheet, and interview guideline. The results of the study are as follow: The social media language are affected the Gayonese language in some types, as they: phonology, morphology, syntax, semantic, and vocabulary. The social media language also affected the character building of the students. The social media language improves the multilingual of the students. It cause the shifting of the self-identity, principal of life, and respect to the culture.
\end{abstract}

Keyword : Students, Language.

\section{Introduction}

By the time, there are changing in languages. The changing are in the aspects of phonology, morphology, syntax, semantic, and lexical [1]. There are a lot of ways that affect the language change, as they: social mobility, education, technology, and so on. In this revolution industry 4.0 technology plays important role in daily life [2]. To custom technology in daily life, people should master the standard language. English has emerged as the necessary standard: the default language, the linguistic equivalent of Windows or the GSM (Global System for Mobile communications) standard[3]. Thus, learning English is useful for the communication and technology development [4].

Nowadays, technology is suitable to be used in learning. Studying conducts by on-line learning. One of the media of on-line learning is social media. Thus, the use of social media today among students is a natural thing and is used in everyday life [5]. Besides, social media is used to access the science and knowledge. Operating the social media could be in English or Indonesia. The user of technology will be a multilingual, because they speak more than one languages [6]. Gayonese speak at least three languages; Gayonese language, Indonesian language, and English. It brings both positive and negative effects to the Gayonese culture [7]. Mastering more languages simplify the access of science and technology. However, multilingual change the culture identity. Language reflects the culture of the speaker. Language and culture cannot be separated one to the other [8]. 
Culture mirrors the characteristics of a group. It includes the rules of communication and interaction [9]. On the other hands, tradition, custom, behaviour, character, residence, association, and language could be said as culture. The existence of a culture depends on the existence of the language. When you lose a language, you lose a culture, intellectual wealth, a work of art [10]. According to the explanation above, it is important to conducting a study in the contributions of social media language in language change and character education. The questions of this study are (1) what are the language changes in reference to the contribution of social media language of the students of IAIN Takengon? And (2) what are the character buildings in reference to the contribution of social media languages of the students of IAIN Takengon? The objectives of this study are finding out the language changes in reference to the contribution of social media language of the students of IAIN Takengon and the character buildings in reference to the contribution of social media languages of the students of IAIN Takengon.

\section{Methodology}

This research was categorized into a case study by using descriptive qualitative approach. Researchers generally do case studies for one of three purposes: to produce detailed descriptions of a phenomenon, to develop possible explanations of it, or to evaluate the phenomenon [11]. The research was conducted in IAIN Takengon in November to December 2019. The participants of this study were the students of IAIN Tekengon. The total number of the students was 1.562 . The purposive sampling was done to take the sample. The goal of purposive sampling is to select persons that can provide the richest and most detailed information to help answering the research questions [12] [13]. The consideration of the sample was students who used the social media at least 8 hours a week.

The data were gathered through interview. The content validity was done to the interview guideline and it was consulted to the expert. The interview was used to collect the data of the students' languages. The researcher conducted and recorded a 15 to 30 minutes interview with each subjects. In doing the interview, the students did not need specific preparation. The students conducted the interview spontaneously. They could speak in their daily language. It was used to get the authentic data [14]. The collected interview recordings were transcribed and classified the data according to the particular classification. Then, the data were identified and counted the language change. The next step was explaining the data.

\section{Result and Discussion}

Gayo, a developing region, concern in improving education quality that support the economic. It encourage the up to dating technology in educational fields. Thus, there are a lot of students master multi languages. The ability to mastered multi language by Gayonese people change the Gayonese language and identity. According to the history, multilingual in Gayo is caused by:

(1) Colonialism 
The colonialism of Netherland in Indonesia for almost 350 years change a lot of element. One of the consequences is the sifting of language and culture, including Gayonese language. The nature language shift morphologically and have lexical diffusion by the speaker.

\section{(2) Migration}

Gayonese expedition tract was developed in 1904 [15]. Since that time, a lot of people came as they: Aceh, Minang, Java, and Chinese. It was caused by job, education, or marriage. The movement of Gayonese people in or out influence to the nature of language. The movement brings new language and culture that shift the Gayonese language and culture.

(3) Internationalization

Trade, export-import, gives a big touch to the Gayonese culture. The mastering of international language is a basic of mastering the technology, so students are motivated to be able to communicate in English fluently. Beside, mastering English support the use of technology in international occupation.

In line to the development of technology, Gayonese language is influenced by the existence social media. The use of social media language are effected the language of the speakers. Multi-literacy acknowledgement of the socio cultural diversity think of our learners' worlds, and awareness of the impact of new communication technologies that combine linguistic modes of meaning with visual, gestural, spatial, and audio modes. Below is the explanation of the language change data.

Table 1. Result of the Language Change

\begin{tabular}{cccc}
\hline No & $\begin{array}{c}\text { Type of Language } \\
\text { Change }\end{array}$ & $\begin{array}{c}\text { Frequ } \\
\text { ency }\end{array}$ & $\begin{array}{c}\text { Percen } \\
\text { tage }\end{array}$ \\
\hline 1 & Phonology & 116 & 15.91 \\
2 & Morphology & 117 & 16.04 \\
3 & Syntax & 103 & 14.12 \\
4 & Semantic & 142 & 19.01 \\
5 & Vocabulary & 251 & 34.42 \\
& Total Number & 729 & 100 \\
\hline
\end{tabular}

In phonology change, there were misspelling (1), and borrowing (2).

(1) The word "if" was pronounced as "ip" in 'I will let my friend knows if I have new account."

(2) The word " $t a b$ " refers to tablet in 'There are a lot of video in my tab.' In morphology, the change was in the form of borrowing (3).

(3) The word "meng-upload" refers to uploaded in "Saya sudah meng-upload foto-foto kemarin ke IG. '(I uploaded the photos to IG yesterday).

In the language change of syntax, there was the use of verb (4).

(4) "Saya sudah WA tapi belum di-read" (I have WA but not read yet). In this sentence should be added the other object to hinder the misunderstanding, as: I sent a message by 'what apps' but not read yet. In semantic change, there was the change of meaning (5).

(5) "akun kita" (our account) refers to my account in 'Cek infonya di akun kita lah.' (Check the information on our account). 
In vocabulary, the changes were in the form of modification (6), borrowing (7), abbreviation (8), and re-exist the old word (9).

(1) The word "bats" or "beud" was used to change the word "banget" (too) in 'Cuaca pagi ini dingin bats.' (the weather was too cold this morning).

(2) The word "update" was permeated in Indonesian sentences in 'sudah baca status yang barusan di-update?' (have you read the updated story?).

(3) The abbreviation of "FB" refers to "Facebook" in 'Add FB ku lah.' (Please, add my Facebook account).

(4) The word "galau" is existing now. This word means worry in 'lagi galau tingkat dewa.' (I am so worry).

The Character is considered as the realization of positive personality development of a person, either intellectually, socially, emotionally, or ethically [16]. To develop students' character concludes seven ways to foster virtues; empathy, conscience, self-control, respect, kindness, tolerance, and justice [17]. The character building could be affected by some treatment. The use of social media languages, as one of the treatments, could be effecting the character building of the students. The effect could be positive and negative. Below is the description of the students' character building that affected by the social media language.

a) According to the data, there are so many students speak multi language. They mix the Gayonese, Indonesia and English in the same discourse. In one side, it motivate students to learn the international language that will be useful for their next career. On the other side, it change the local value of Indonesian people. The use of English in daily conversation lower the respect to the older people. For example, in a conversation of a son and parent, according to the Gayonese culture, it is taboo for the son to look at his parent's face when he is talking. However, in English literature, the speakers should face to face. Nowadays, the norm is crossed by young people. It means that there is changing in the character of respect. Next example, in Gayonese culture it is taboo to call older people by 'you'. They should be called as Sir or Mam. It is crossed by the youth when they have conversation in English.

b) Self-identity of Gayonese is Mukemel (self-concept) [18]. To reach self-concept, someone should apply some value, as they: Tertip (orderly), Setie (loyal), Semayang-Gemasih (affection), Mutentu (hard work), Amanah (believed), Genap-Mupakat (discuss), AlangTulung (helpful), Bersikekemelen (competitive) [19]. The values connect one to each other. The sifting of Gayonese self-identity can be looked in the learning activities. The low motivation of the students to compete reduce their enthusiasm to work hard. According to the Gayonese's self-identity, it can be seen that Gayonese people have great self-concept that frame their live. However, the influence of the arrival culture to the genuine culture in the daily live lower the soul of self-concept.

c) The principal of life in Gayonese culture is reflected in the avoiding Sumang. Sumang means acts deviate from convention of manners and contrary to Islamic rules and custom [20]. It devided into four, they are: Sumang Kenulen (ethics sit), Sumang Percerakan (ethics talk), Sumang Pelangkahan (ethics walk), and Sumang Penengonen (ethics see) [21] [22]. The violation of Sumang that influenced by social media language is ethics talk. For example, updating story in the social media with insulting statement or telling someone's disgrace are often done by youth.

Next, the Gayonese principal of life is Peri Mestike [23] agama orum edet lagu zet orum sipet (religion and culture is an inseparable cohesiveness); syariet berules edet bersebu (sharia conducted inline to culture) [24], beras padi tuket imen. It means that the 
appropriateness of physical needs strengthen the spiritual needs. The fulfilled of physical needs; primary, secondary, and tertiary facilitate to reach the higher spiritual achievement. For example, conducting Hajj when someone is wealth. Nowadays, the youth choose Umrah or traveling than Hajj. On the other hands, the sifting of life's principal is the property investment, as build big houses, buy luxury vehicles, and so on than conducting spiritual investment. It contradict to the requirement of happiness life of Gayonese culture.

d) The youth give minor respect to the existence to Gayonese culture. It can be seen in their attitude of the lost Gayonese language. Some words of Gayonese language lost because rarely used in the communication. In the daily interaction, youth ignore to avoiding Sumang. In the formal education, students have little understanding about the Gayonese principal of life, Peri mestike. It can be seen by the difficulties to pass the lesson of Literature Budaya Gayo. Avoiding the fade of Gayonese language and literature, there are a lot of things to be conducted. In education field, the school curriculum should be integrated to the local culture. It should be consistent from the elementary to the higher education. In the sociable life, Sarak Opat obliged to maintain the self-concept of the people. Sarak Opat is a discussion institution that include Reje (region leader), Imem (religion leader), Petue (respected person), Rakyat Genap Mupakat (consensus public) [25]. When the formal and informal education are conducted in line to the Gayonese principle of life, the existence of Gayonese language, culture, and local wisdom will be glorious.

\section{Conclusion}

The use of technology, especially in communication, increase the multilingual. The social media language are affected the Gayonese language in some types. They are: phonology (15.91\%), morphology (16.04\%), syntax (14.12\%), semantic (19.01\%), and vocabulary $(34.42 \%)$. On the other hands, the social media language also affected the character building of the students. The social media language improves the multilingual of the students. It cause the shifting of the self-identity, principal of life, and respect to the culture. Besides, the minor respect to the youths' attitude endanger the existence of Gayonese culture. To keep the existence of Gayonese culture, both formal and informal education should be conducted in line to the Gayonese principle of life.

\section{References}

[1] S. K. Wahyuningsih, "Perubahan Bahasa dan Budaya Jawa di Yogyakarta Pada Era Globalisasi," J. As-Salam, vol. 2, no. 2, pp. 53-59, 2018, doi: 10.37249/as-salam.v2i2.33.

[2] L. A. Daulay, F. Firmansyah, and R. Zakaria, "The Development of E-Learning Media Based Moodle to Increase Science Development and Islamic Studies in STAIN Gajah Putih," Al-Ta lim J., vol. 24, no. 2, p. 103, 2017, doi: 10.15548/jt.v0i0.275.

[3] J. Aitchinson and D. M. Lewis, New Media Language. London: Routledge, 2003.

[4] A. H. Surbakti, "Pembelajaran Bahasa Ditinjau dari Segi Aksiologi," J. As-Salam, vol. 1, no. April, pp. 18-23, 2017, doi: http://jurnal-assalam.org/index.php/JAS/article/view/72.

[5] A. K. P. Nasution, "Integrasi Media Sosial Dalam Pembelajaran Generasi Z," vol. 13, no. 277, 2020, doi: https://doi.org/10.24036/tip.v13i1. 
[6] B. O. Okal, "Benefits of Multilingualism in Education," Univers. J. Educ. Res., vol. 2, no. 3, pp. 223-229, 2014, doi: 10.13189/ujer.2014.020304.

[7] J. Cenoz and D. Gorter, "Minority Languages, National State Languages, and English in Europe: Multilingual Education in the Basque Country and Friesland," J. Multiling. Educ. Res., vol. 9, no. 1, p. 9, 2019, doi: https://research.library.fordham.edu/jmer/vol9/iss 1/9.

[8] A. Wedin, "Negotiating identities through multilingual writing: Local school policy that opens up spaces for students' diverse languages," Linguist. Educ., vol. 55, p. 100775, 2020, doi: 10.1016/j.linged.2019.100775.

[9] A. Chaer and Agustina, Sosiolinguistik Perkembangan Awal. Jakarta: Rineka Cipta, 2004.

[10] B. Spolsky and F. Hult, The Handbook of Educational Linguistics. Oxford: Blackwell Publisher, 2008.

[11] M. D. Gall, J. P. Gall, and W. r Borg, Educational Research: an Introduction. New York: Long Man, 2003.

[12] M. G. Lodico, D. t Spaulding, and K. H. Voegtle, Method in Educational Research. San Francisco: John Wiley \& Sons, Inc, 2010.

[13] S. K. Wahyuningsih, "Group Work to Improve Classroom Interaction and Students' Self-Esteem of STAIN GPA,” Res. Innov. Lang. Learn., vol. 1, no. September, pp. 187-200, 2018, doi: http://dx.doi.org/10.33603/rill.v1i3.1125.

[14] S. K. Wahyuningsih, "Grammatical errors analysis in the descriptive writing of the semester 3 students of English Education Department of STAIN Gajah Putih,” J. Educ., vol. 1, no. 1, pp. 60-65, 2016, doi: https://journal.uny.ac.id/index.php/joe/article/view/9613.

[15] M. Paeni, Riak di Laut Tawar. Yogyakarta: Penerbit Ombak, 2016.

[16] S. A. Kamaruddin, "Character Education and Students Social Behavior," J. Educ. Learn., vol. 6, no. 4, p. 223, 2012, doi: 10.11591/edulearn.v6i4.166.

[17] N. Listiawati, "The Implementation of the Strengthening Character Education in Sdn 09 Mataram City, Ntb," J. Pendidik. Karakter, vol. 8, no. 1, pp. 17-28, 2019, doi: 10.21831/jpk.v0i1.18257.

[18] S. Syukri, "Budaya Sumang Dan Implementasinya Terhadap Restorasi Karakter Masyarakat Gayo Di Aceh," MIQOT J. Ilmu-ilmu Keislam., vol. 41, no. 2, pp. 406-427, 2018, doi: 10.30821/miqot.v41i2.428.

[19] S. Abdi, "Konsep Nilai Islam,” J. Pendidik. Islam, vol. 2, no. 2, pp. 1-9, 2019, doi: https://uia.ejournal.id/Tahdzib/article/view/514.

[20] Jamhir, "Nilai-Nilai Adat Gayo Bersandarkan Hukum Islam Sebagai Pedoman Dalam Menyelesaikan Kasus Hukum Pada Masyarakat Gayo," J. Justitia, vol. 2, no. 1, pp. 1-25, 2017, doi: http://dx.doi.org/10.22373/justisia.v2i1.2645.

[21] M. Ibrahim and A. Pinan, Syari'at dan Adat Istiadat. Takengon: Yayasan Maqamam Mahmuda, 2002.

[22] Evanirosa, "Pendidikam Nilai Dalam Budaya Sumang Etnik Gayo," vol. 21, no. 1, pp. 1-9, 2020, doi: http://dx.doi.org/10.36418/syntax-literate.v5i6.1325.

[23] Indra, A. Rasyidin, and Sukirman, "Internalization of Falsafah 'Peri Mestike Gayo' as an Effort To Developing Students ' Characters Based on Local Authority In SMA 1 Takengon Aceh Central District," Int. J. Educ. Vocat. Stud., vol. 1, no. 8, pp. 817-822, 2019, doi: https://doi.org/10.29103/ijevs.v1i8.2236.

[24] Sutrisno and J. Harnedi, "Membangun Masyarakat Sadar Wisata dan Sadar Bencana di Kawasan Danau Lut Tawar Takengon," J. As-Salam, vol. 2, no. 3, pp. 93-102, 2018, doi: https://doi.org/10.37249/as-salam.v2i3.104.

[25] A. Abdullah and Armiyadi, "Peran Lembaga Sarak Opat Dalam Menyelesaikan Kasus kekerasan Dalam Rumah Tangga (KDRT)," Legitimasi, vol. 7, no. 1, pp. 1-26, 2018, doi: http://dx.doi.org/10.22373/legitimasi.v7i1.3962. 
